\title{
Selective Citizenship: How the Court of Justice Linked Security of Residence to Integration
}

\author{
Bernard Ryan \\ Professor of Migration Law, University of Leicester, UK \\ Br85@leicester.ac.uk
}

\begin{abstract}
This article examines the case-law of the Court of Justice concerning security of residence for EU citizens and family members under Directive 2004/38. The relevant provisions of the Directive confer a right of permanent residence, and enhanced protection against expulsion, upon longer-term residents. It is argued that, in interpreting these provisions from 2006 onwards, the Court of Justice adopted a discourse which conceived of the rights as dependent on an individual's social integration. The initial effect of the Court's 'turn' to integration was benign, as it supported the retrospective extension of permanent residence, and ensured the efficacy of enhanced protection against expulsion. Later, however, the Court would treat integration as a precondition, in ways which would limit the rights of long-term residents who were not economically active or self-sufficient, or who had been sentenced to periods of imprisonment. That Court's integration discourse was presumably influenced by developments in policy concerning third-country nationals at the state level which had linked immigration status to integration tests. The result was a selective approach to security of residence, which tended to deny protection to persons whose presence was unlikely to be favoured by Member States.
\end{abstract}

\section{Keywords}

EU citizenship - integration - permanent residence - deportation

\footnotetext{
(C) BERNARD RYAN, 2019 | DOI:10.1163/15718166-12340056

This is an open access article distributed under the terms of the CC-BY-NC license.
} 
The history of the free movement rights of EU citizens and their family members has for the most part been one of gradual expansion. In the 196os and 1970s, EU law developed as 'market citizenship', with extensive rights of residence progressively conferred upon EU citizens who engaged in economic activity in other Member States, and their family members. ${ }^{1}$ In the 1980 s and early 1990s, the free movement regime then moved beyond economic activity, with the Court of Justice protecting students in other Member States, and legislation conferring a right of residence upon all persons with sufficient means and comprehensive sickness insurance. ${ }^{2}$ Further developments would follow the creation in 1993 of the status of citizen of the European Union, which entailed 'the right to move and reside freely within the territory of the Member States. ${ }^{3}$ EU citizenship was the background to the 2004 Citizens Directive, which both confirmed and added to the previous corpus of free movement rights. ${ }^{4} \mathrm{EU}$ citizenship also provided the basis for Court of Justice rulings conferring a right of residence upon certain family members of EU citizens in circumstances not covered by the Directive. ${ }^{5}$

This article will address an aspect of EU free movement law where a progressive narrative seems inappropriate, however: the interpretation by the Court of Justice of provisions concerning security of residence added by the Citizens Directive. The provisions in question ostensibly confer a general right of permanent residence, after five years' lawful residence, and a higher degree

1 M. Everson (1995) 'The Legacy of the Market Citizen', in: J. Shaw \& G. More, New Legal Dynamics of the European Union (Oxford, Clarendon Press).

2 Case 293/83 Gravier v. City of Liège, EU:C:1985:69 [1985] ECR 593, Directive 90/ 364 on the right of residence [1990] OJ L 180/26, Directive 90/365 on the right of residence for employees and self-employed persons who have ceased their occupational activity [1990] OJ L 180/28, and Directive 90/366 on the right of residence for students 1990] OJ L 180/30 (re-adopted as Directive 93/96 [1993] OJ L 317/59).

3 N. Reich (2001) 'Union Citizenship-Metaphor or Source of Rights?', 7 European Law Journal 4, p. 10-15; F. Wollenschläger (2012) 'The Judiciary, the Legislature and the Evolution of Union Citizenship', in: P. Syrpis (ed.), The Judiciary, the Legislature and the Single Market (Cambridge, Cambridge University Press).

4 Directive 2004/38 on the right of citizens of the Union and their family members to move and reside freely within the territory of the Member States [2004] OJ L 158/77 discussed in D. Kostakopoulou (2005) 'Ideas, Norms and European Citizenship: Explaining Institutional Change', 68 Modern Law Review 233, 260-261; E. Guild (2007) 'Citizens without a Constitution, Borders without a State: EU Free Movement of Persons', in A. Baldaccini, E. Guild and H. Toner (eds), Whose Freedom, Security and Justice? EU Immigration and Asylum Law and Policy (Oxford, Hart), p. 29-30.

5 Discussed further in section 4 , below. 
of protection against expulsion for public policy reasons upon longer-term residents. The argument advanced in the article is that, in interpreting these provisions, the Court of Justice came to be influenced by a new policy discourse in western European states in the late 1990s and early 2000s, which made immigration status conditional upon social integration. The article will show howin its language, and in the logic of its rulings - the Court developed a discourse of social integration which led to a narrow construction being placed on security of residence rights, but which lacked support in the text of the Directive.

The body of the article will begin, in section 2, by charting the development of security of residence guarantees within EU law on the free movement of persons, up to and including the relevant provisions of the Citizens Directive. Section 3 will then consider the evolution of concepts of social integration in EU legislation and case-law, focusing upon the 'turn' to integration in the period around 2000. The jurisprudence of the Court of Justice concerning the additional rights in the Citizens Directive is examined in two further sections, covering the right of permanent residence and protection against expulsion respectively (sections 4 and 5). In these sections, it will be seen that the initial effect of the Court's integration discourse was a benign one, in that it supported the extension or protection of the rights set out in the Directive. Later, however, the Court came to treat integration as a precondition to protection, in ways which limited the rights of long-term residents who were not economically active or self-sufficient, or who had been sentenced to periods of imprisonment. The concluding section will argue that the Court's integration discourse has resulted in a 'selective' approach to security of residence, which excludes specific categories of EU citizen and their family members whose presence is unlikely to be favoured by Member States.

\section{Security of Residence in EU Free Movement Law}

In comparative migration policy, the notion of 'security of residence' can be said to have two elements. ${ }^{6}$ Firstly, it involves an individual's having a residence status which is not, or is no longer, contingent upon their meeting specific qualifying conditions, such as employment, a family relationship, adequate resources etc. Secondly, it implies a high degree of protection against expulsion after the commission of criminal offences, or other conduct deemed

6 See, for example, K. Groenendijk, E. Guild \& H. Dogan (1998) Security of Residence of Long-Term Migrants: A Comparative Study of Law and Practice in European Countries (Strasbourg, Council of Europe), p. 98-101. 
anti-social. These two elements together make it possible for a foreign national to live in another state in conditions of broad equality with its nationals. In practice, in western Europe, in the period from the 1960s to the 1980s, these two elements came to be reflected in forms of long-term residence status. ${ }^{7}$ The question to be addressed here is how far EU free movement legislation has protected security of residence in these senses, both prior to the Citizens Directive, and after its coming into effect. ${ }^{8}$

\subsection{Residence without Conditions in EU Free Movement Law}

When the free movement of persons was elaborated piecemeal through secondary legislation from the 1960 s to the 1990s, no general provision was made for the security of residence in the sense of freedom from qualifying conditions. Accordingly, rights of residence depended upon continuing compliance with qualifying conditions of economic activity, financial self-sufficiency or family membership. (In this article, residence in accordance with these conditions is termed 'qualifying residence'.) The only right of permanent stay was conferred upon EU nationals who were former workers and self-employed persons, and their family members, after the EU national's retirement, permanent incapacity, or their taking employment in another Member State. ${ }^{9}$

The right of long-term residents to remain in a Member State without conditions would be transformed by the 2004 Citizens Directive, with effect from 30 April 2006. Its Article 16 provides a general right of permanent residence for EU citizens who have 'resided legally for a continuous period of five years in the host Member State', and upon non-EU national family members who have 'legally resided with' the EU citizen for the same length of time. ${ }^{10}$ In the acquisition phase of the right of permanent residence, Article 16(3) provides that continuity of residence may be maintained during absences of up to six months a year, for up to twelve months for 'important reasons' such as pregnancy and childbirth, serious illness, study, vocational training or posting by an employer, and for longer periods for compulsory military service. The rights of

7 W. Brubaker (1989) 'Membership without Citizenship: The economic and social rights of non-citizens', in: W. Brubaker (ed.), Immigration and the Politics of Citizenship in Europe and North America (Lanham, University Press of America).

8 This question assumes that it is possible to compare the rights of EU citizens and their family members to those of third-country nationals. The article as a whole can be said to validate that assumption, in that it confirms that security of residence is not absolute for those eligible under EU free movement law.

9 Regulation $1251 / 70$ on the right of workers to remain in the territory of a Member State after having been employed [1970] OJ L 142/24 and Directive 75/34 concerning the right to remain after having pursued an activity in a self-employed capacity [1974] OJ L 14/10. 
permanent stay previously conferred upon former workers and self-employed and their family members, which either have shorter qualifying periods, or none at all, are preserved in Article 17 of the Directive. Finally, Article 18 provides that non-EU nationals who were formerly the qualifying family members of an EU citizen may acquire a right of permanent residence after five years' lawful residence, if they have retained a right of residence under the Directive. ${ }^{11}$

The generalised right of permanent residence set out in the Directive fits the ideal of a secure residence status. Firstly, a right to reside no longer depends upon meeting the standard qualifying conditions in Article 7 of the Directive. ${ }^{12}$ Instead, according to Article 16(4) of the Directive, the right of permanent residence can be lost 'only through absence from the host Member State for a period exceeding two consecutive years'. Secondly, the right of permanent residence ensures full equal access to social provision in the host Member State. ${ }^{13}$ Thirdly, it is arguable that the right of permanent residence may permit the sponsorship of family members without the sponsor's meeting the requirements for ordinary residence. ${ }^{14}$ Finally, depending on the law and policy in individual Member States, possession of the right of permanent residence may give access to the nationality of the state of residence, both by the individual, and by any of their children born in that state. ${ }^{15}$

\subsection{Protection against Expulsion}

In the decades prior to the Citizens Directive, security of residence in the sense of protection against expulsion was achieved primarily through Directive $64 / 221$, which eventually applied to all categories of person with a right of residence under EU free movement law. ${ }^{16}$ That Directive covered both the substantive and the procedural aspects of decisions affecting residence taken on public order grounds-i.e., exclusion, refusal of a residence document, and

11 The retained rights which may be relied upon are those provided for in Articles 12(2) and 13(2) of the Directive.

12 Directive 2004/38, Article 16(1), second sentence: 'This right shall not be subject to the conditions provided for in Chapter II.'

13 See the terms of Article 24 of the Directive.

14 See Case E-4/11 Clauder, EFTA Court, 26 July 2011. The case concerned the extension of the Citizens Directive to the three EEA states by Decision 158/ 2007 of the EEA Joint Committee (OJ $2008 \mathrm{~L} 124 / 20)$. The Court of Justice has not ruled on this point.

15 For example, this is explicit in the law of the United Kingdom: see the Immigration (European Economic Area) Regulations 2016 (SI 2016 No. 1052), Schedule 3, para 2.

16 Directive 64/221 on measures concerning the movement and residence of foreign nationals which are justified on grounds of public policy, public security or public health [1964] OJ L 56/850 and Article 2(2) of each of Directive 9o/364, Directive 9o/365 and Directive $93 / 96$. 
expulsion. In particular, its Article 3 set out the core principle that 'measures taken on grounds of public policy or of public security shall be based exclusively on the personal conduct of the individual concerned' and that 'previous criminal convictions shall not in themselves constitute grounds for the taking of such measures'. In Bouchereau, the Court added that, to justify an expulsion or exclusion measure, a person's conduct or criminal offence(s) had to amount to a 'genuine and sufficiently serious threat to the requirements of public policy affecting one of the fundamental interests of society.'17 These legal principles applied irrespective of an individual's length of stay in a state. That said, in Orfanopoulos and Oliveri the Court held that expulsion decisions had to respect the principle of proportionality, which in turn required the duration of residence in the Member State to be taken into account. ${ }^{18}$

In relation to expulsion, the Citizens Directive both replaced Directive $64 / 221$ and made several changes which benefited long-term residents. ${ }^{19}$ Firstly, under Article 28(1) of the Directive, the protection available in all cases was strengthened by a statement that a Member State should take account of a range of factors, including length of residence and 'social and cultural integration into the host Member State'. Secondly, Article 28(2) provided that persons with a right of permanent residence could not be expelled 'except on serious grounds of public policy or public security'. Thirdly, Article 28(3) provided that EU citizens (only) who had 'resided in the host Member State for the previous 10 years', or who were minors, could not be expelled other than on 'imperative grounds of public security'.

3 Concepts of Integration in EU Free Movement Law

The 'integration' of migrants is to be understood analytically, without any normative commitment to it as a goal, as being concerned with processes of inclusion and acceptance in a given society. ${ }^{20}$ Before discussing the interpretation

17 Case 30/77 Rv. Bouchereau, EU:C:1977:141 [1977] ECR 1999, paras 28 and 30.

18 Joined Cases C-482/o1 and C-483/o1 Orfanopoulos and Oliveri, EU:C:2004:262 [2004] ECR I-5257, paras 95-99. The Court drew upon the European Court of Human Rights judgment in Boultif v. Switzerland (Application no. 54273/oo, judgment of 21 August 2001) concerning the right to family and private life in Article 8 ECHR.

19 A further change saw the incorporation of the Bouchereau test into the text of the legislation: see Directive 2004/38, Article 27(2).

20 See R. Penninx \& B. Garcés-Mascareñas (2016) 'The concept of integration as an analytical tool and as a policy concept', in: B. Garcés-Mascareñas \& R. Penninx (eds), Integration Processes and Policies in Europe: Contexts, Levels and Actors (Cham, Springer Open), p. $13-14$. 
of the provisions of the Citizens Directive concerning security of residence, we must consider the main ways in which the relationship between the immigration status and rights of foreign nationals, and the policy goal of integration of migrants, have been conceived. That question is approached here by asking how public policy itself understands that relationship. The reason for such a focus is that - as Favell has argued - recent debates over migrant integration in Europe have essentially been about 'imagining what the state can actively do to 'nationalize' newcomers and re-constitute the nation-state under conditions of growing cultural diversity'. ${ }^{21}$

Three public policy approaches to the status-integration relationship - all of which appear in EU free movement law-may be identified. The first is an 'egalitarian' approach, which treats security of residence and equality of rights as means to the goal of enhancing the social integration of migrants. ${ }^{22}$ The second is a 'residence-based' approach to integration. This allows that a given immigration status or rights may be conditional upon integration, but infers integration from periods of actual residence, without further elements being required. The third approach is an 'actively conditional' one. Within that approach, the relationship between status and integration is fully reversed, and the acquisition of a given immigration status is made conditional upon actual social integration. In practice, we shall see below that different types of condition are possible under this heading: requirements of economic activity or financial self-sufficiency may be understood as linked to integration; so may respect for the criminal law and social values may be required; and, there may be requirements as to knowledge of the predominant language or of the operation of the society or state in question.

To the extent that immigration policy and migrant integration were thought to be linked in the period from the 1960 s to the 1990s, the typical policy perspective was the egalitarian one that improvements in status and rights tended to improve social integration. ${ }^{23}$ Within EU law, that was seen in particular in relation to Regulation $1612 / 68$ on the free movement of workers. ${ }^{24}$ Its

21 A. Favell (2010) 'Integration Nations: The Nation-State and research on immigrants in Western Europe' (2003) 22 Comparative Social Research 13. The version relied upon here is that re-published in M. Martiniello \& J. Roth (eds), Selected Studies in International Migration and Immigrant Incorporation (Amsterdam, Amsterdam University Press), at p. 376-377.

This approach has been summarised by Groenendijk as follows: 'a secure legal status will enhance the immigrant's integration in society; a strong residence status and equal treatment are instruments for integration'. See K. Groenendijk (2004) 'Legal Concepts of Integration in EU Migration Law', 6 European Journal of Migration and Law, p. 111, 113.

23 Ibid., p. 114.

24 Ibid. 
Preamble referred to 'the integration of [a migrant worker's] family into the host country' as a justification for conferring rights of residence, economic activity and equal treatment upon those family members. ${ }^{25}$ The language of integration would be relied upon by the Court to support later findings that, under the Regulation, the children of migrant workers were entitled to remain in a Member State to complete their education, and to equal treatment in finance for study abroad. ${ }^{26} \mathrm{~A}$ similar understanding of the potential for rights to contribute to migrant integration was evident in statements by the Court of Justice concerning Decision 1/8o on the labour market rights of Turkish workers and their family members. ${ }^{27}$ In Kadiman, decided in 1997, the Court stated that family members were granted rights to take up employment in order to deepen the integration of a migrant Turkish worker's family unit in the host Member State. ${ }^{28}$ The same year, the Court declared in Eker that the progressive removal of restrictions on Turkish workers' employment was aimed at their 'gradual integration ... in the host State's labour force.' ${ }^{29}$

In the late 1990s and early 2000s, however, the content of immigration policy would come to shaped by European governments' responses to a perceived lack of social and economic integration by certain groups of migrant origin. ${ }^{30}$ A new direction for immigration policy was signalled by the Newcomer Integration Law of 1998 in the Netherlands, which obliged most new non-EU

25 Regulation 1612/68 on freedom of movement for workers within the Community [1968] OJ L 257/2.

26 Joined Cases $389 / 87$ and 390/87, Echternach and Moritz v. Minister van Onderwijs en Wetenschappen, EU:C:1989:130 [1989] ECR 723, paras 20-21; Case C-308/89 Di Leo v. Land Berlin, EU:C:1990:400 [1990] ECR I-4185, paras 9-13. The language of integration would continue to be utilised in subsequent judgments concerning the implications of the educational rights of the children of migrant workers: see Case C-413/99 Baumbast and $R v$. Secretary of State for the Home Department, EU:C:2002:493 [2002] ECR I-7091, paras 50-53, 59 and 68; Case C-310/o8 London Borough of Harrowv. Ibrahim, EU:C:2010:80 [2010] ECR I-1065, paras 43, 54 and 55; Case C-480/08 Teixeira v. London Borough of Lambeth, EU:C:2010:83 [2010] ECR I-1107, para 66; and Case C-45/12 Office national d'allocations familiales pour travailleurs salariés v. Hadj Ahmed, EU:C:2013:390, paras 44-45.

27 Groenendijk 2004, p. 115.

28 Case C-351/95 Kadiman v. Freistaat Bayern, EU:C:1997:205 [1997] ECR I-2133, para 35.

29 Case C-386/95 Ekerv. Land Baden-Württemberg, EU:C:1997:257 [1997] ECR I-2707, para 23. This latter would be frequently repeated by the Court: see For example Case C-1/97 Birden v. Stadtgemeinde Bremen, EU:C:1998:568 [1998] ECR I-7747, para 37 and Case C-340/97 Nazliv. Stadt Nürnberg, EU:C:2000:77 [2000] ECR I-957, para 30.

$3^{0}$ W. Brubaker (2001) 'The return of assimilation? Changing perspectives on immigration and its sequels in France, Germany, and the United States', 24 Ethnic and Racial Studies, p. 531-548; R. Koopmans (2013) 'Multiculturalism and immigration: A contested field in cross-national comparison', 39 Annual Review of Sociology, p. 147-169. 
migrants to take a 12-month language and civic integration course. ${ }^{31}$ Over the next decade, most western European states would make family sponsorship, permanent residence status and naturalisation conditional upon requirements concerning language and/or civic knowledge. ${ }^{32}$ These developments were in line with the 'actively conditional' approach identified above, that immigration status should be dependent upon evidence of social integration, or of a capacity for it.

That trend in state policy would be reflected in legislation at the EU level. The 2003 Long-Term Residents Directive provided that a Member State could make the grant of long-term residence status conditional upon compliance with 'integration conditions'. ${ }^{33}$ Similarly, the Family Reunification Directive, also adopted in 2003, permitted the admission of family members of thirdcountry nationals to be linked to 'integration measures'. ${ }^{34}$ The new policy agenda was further reflected in the Common Basic Principles for Immigrant Integration Policy adopted by the Council of Ministers in November 2004. While that did not specifically address the place of integration requirements within immigration law, it supported the 'actively conditional' approach through its statement that integration implied 'basic knowledge of the host society's language, history, and institutions' ${ }^{35}$

Around the same time, the jurisprudence of the Court of Justice concerning EU free movement law began to deviate from the previous narrative that rights support the integration of foreign nationals. In Givane, decided in 2003, the Court had to interpret the provision for the family members to remain in a host Member State after an EU worker's death, then contained in Regulation 1251/70. It observed that the requirement that the worker have resided in a Member State continuously for two years was intended inter alia 'to ensure a certain level of their integration in the society of that State. ${ }^{36}$ In

31 H. Entzinger (2003) 'The Rise and Fall of Multiculturalism: The Case of the Netherlands', in: C. Joppke \& E. Morawska (eds), Toward Assimilation and Citizenship: Immigrants in Liberal Nation-States (Basingstoke, Palgrave MacMillan).

32 For details of national developments, see C. Joppke (2007) 'Beyond National Models: Civic Integration Policies for Immigrants in Western Europe', 30 West European Politics, p. 1-22; S. Wallace Goodman (2012), 'Fortifying citizenship: Policy strategies for civic integration in Western Europe', 64 World Politics, p. 659-698.

33 Directive 2003/109 concerning the status of third-country nationals who are long-term residents [2004] OJ L 16/44, Art 5(2).

34 Directive 2003/86 on the right to family reunification [2003] OJ L 251/12, Article 7(2).

35 Published in the Council of Ministers press release 'Justice and Home Affairs meeting, 19 November 2004' (Council document 14615/04), p. 15-24.

36 Case C-257/oo Givane v. Secretary of State for the Home Department, EU:C:2003:8 [2003] I-345, para 46. 
Bidar, decided in 2005, the Court held that it was compatible with the principle of equal treatment of EU citizens for a Member State to limit student financial support to those 'who have demonstrated a certain degree of integration into the society of that State'. ${ }^{37}$ The decision in Bidar permitted a Member State to require a minimum period of residence prior to conferring eligibility to student support, and in the subsequent case of Förster, the Court would follow the same reasoning to permit a requirement of five years' residence. ${ }^{38}$ In these three judgments, for the first time, the Court presented integration as a pre-condition to the acquisition of certain rights. This new understanding of integration was the moderate, 'residence-based' approach referred to, in that it understood integration to flow solely from periods of actual residence.

Because of the general 'turn' to integration in immigration policy in Europe around 2000, referred to above, it is not surprising that that terminology is used in three places in the Citizens Directive. Firstly, reference was made to the goal of integration to justify the new general right of permanent residence. Recital 17 states that 'enjoyment of permanent residence by Union citizens who have chosen to settle long term in the host Member State ... is a key element in promoting social cohesion, which is one of the fundamental objectives of the Union'. Recital 18 then provides that 'in order to be a genuine vehicle for integration into the society of the host Member State ... the right of permanent residence, once obtained, should not be subject to any conditions'. These statements fell squarely within the egalitarian approach, with secure residence status treated as a means to social cohesion and integration. ${ }^{39}$

Secondly-as mentioned in section 2-'social and cultural integration' was included in Article 28(1) of the Directive among the factors to be considered in any expulsion decision. Taken literally, this formulation permits an evaluation of an individual's degree of integration, separate from residence as such, which could potentially work either for or against the individual concerned. Nevertheless, the reason for its insertion appears to have been to reduce the scope for expulsion, with the Commission stating in the original proposal that the aim was to 'provide greater protection against expulsion by taking account of how integrated the Union citizen is in the host country'. ${ }^{40}$ That understanding was reflected in recital 23 to the Directive, according to which the expulsion of EU citizens and family members 'can seriously harm persons who, having

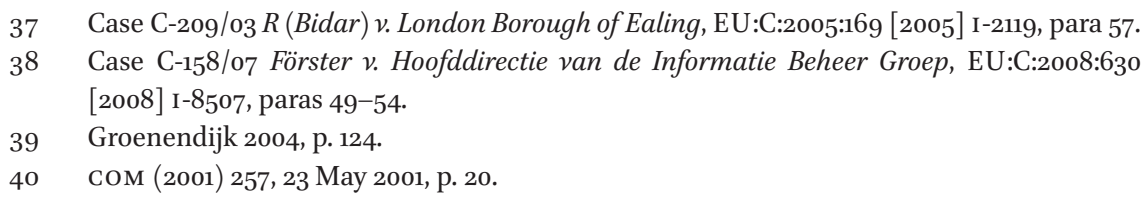


availed themselves of the rights and freedoms conferred on them by the Treaty, have become genuinely integrated into the host Member State'. Here, the approach to integration was the second one identified above, that residence by EU citizens and family members in a given Member State would inherently lead to their being integrated there.

Thirdly, 'integration' was referred to in the explanation within the Directive of the high level of protection against expulsion conferred upon EU citizens with more than ten years' residence. According to recital 24, 'the greater the degree of integration of Union citizens and their family members in the host Member State, the greater the degree of protection against expulsion should be'. The possible implication that this protection was conditional upon an individual's being integrated was however dispelled by the further statement in recital 24 that 'only in exceptional circumstances ... should an expulsion measure be taken against Union citizens who have resided for many years in the territory of the host Member State'. By linking length of residence to the extent of protection, the reference to 'integration' in recital 24 again fitted with the second approach.

Taken as a whole, the references to integration in the Court's case-law in 2003-2005, and in the text of the Directive, showed support for the new position that residence itself led to integration. In particular, nothing in the textual references in the Directive suggests that it was intended to go further, to make long-term residents' rights conditional upon integration, as a separate requirement. We shall see however in sections 4 and 5 that the Court of Justice would come to pursue an 'actively conditional' approach to integration when it interpreted the Directive's provisions relating to security of residence.

The Court initially developed its discourse of integration in rulings on three questions concerning acquisition of the right of permanent residence, considered in turn here: the treatment of periods of time prior to the Directive's application, the types of residence which count, and the effect of time spent in prison.

\subsection{Pre-Directive Periods}

The earliest question concerning permanent residence considered by the Court was whether a period of qualifying residence, under EU free movement law, which both began and ended before 30 April 2006, counted towards that right. That question arose in Lassal, which concerned a French national who 
had been a worker in the United Kingdom continuously from 1999 to $2005^{41}$ In its ruling in October 2010, the Court held that pre-Directive periods of residence which were in accordance with earlier EU legislation counted. ${ }^{42}$ Later, in Ogieriakhi, decided in July 2014, it would extend this principle to cover preDirective periods of residence by third-country national family members. ${ }^{43}$

The Court reached a related conclusion in Ziolkowski and Szeja, which concerned two principal applicants of Polish nationality who had resided in Germany for many years on the basis of humanitarian residence permits. ${ }^{44}$ After Poland joined the EU on 1 May 2004, they had been refused extensions to their residence permits, and had been ordered to leave Germany, on the ground that they lacked sufficient resources. The central issue was whether they could count periods of residence which pre-dated the accession to the EU by their state of nationality towards the right of permanent residence. In its judgment in December 2011, the Court concluded that it was possible to do so. ${ }^{45}$

The effect of the rulings in Lassal, Ogieriakhi and Ziolkowski and Szeja was to recognise a 'latent' right of permanent residence which came into being once the Directive took effect in relation to a given person. That result was though difficult to reconcile with recital 17 to the Directive, which states that the right of permanent residence is for persons who have 'resided in the host Member State in compliance with the conditions laid down in this Directive'. How could that be said of periods of time when the Directive did not apply?

The Court's defence of its broad position is contained in the Lassal judgment. ${ }^{46}$ There, the Court firstly referred to the goal of social cohesion contained in recital 17.47 More importantly, it referred to the objective of 'integration':

\footnotetext{
41 Case C-162/og Secretary of State for Work and Pensions v. Lassal, EU:C:2010:592 [2010] ECR I-9217.

$42 \quad$ Ibid., para 36.

43 Case C-244/13, Ogieriakhi v. Minister for Justice and Equality, EU:C:2014:2068, 10 July 2014.

44 Joined Cases C-424/10 and C-425/10 Ziolkowski and Szeja and others v. Land Berlin, EU:C:2011:866 [2011] ECR I-14051. The Szeja part of the proceedings also concerned the main applicant's two children. They were Polish nationals too: see the decision of the Bundeverwaltungsgericht of 13 July 2010 (BVerwG 1 C 15.09), para 1.

45 Ziolkowski and Szeja, paras 56-63.

46 Although its reasoning concerning social cohesion and integration was not repeated in Ogieriakhi and Ziolkowski and Szeja, the Court relied upon Lassal in support of an expansive approach to periods before the Directive applied: Ogieriakhi, para 29, Ziolkowski and Szeja, paras 58 and 62 .

Lassal, para 32 .
} 
The EU legislature made the acquisition of the right of permanent residence ... subject to the integration of the citizen of the Union in the host Member State ... [I]t would be incompatible with [that] integrationbased reasoning ... to consider that the required degree of integration in the host Member State depended on whether the continuous period of five years' residence ended before or after 30 April 2006. ${ }^{48}$

This passage can be said to be in line with the progressive history of EU free movement law, as the Court's aim was to widen the reach of the right of permanent residence by enabling reliance upon older periods of residence. In order to justify that outcome, however, it treated the right of permanent residence as conditional upon integration ('subject to'). That was though a questionable reading of the Directive's provision for permanent residence, given that - as we saw in the previous section-recital 18 reflects the egalitarian perspective that security of residence is a means to the integration of EU citizens and family members. While the effect of introducing integration into its reasoning was expansive on that occasion, it would lead to a narrowing of rights in other contexts.

Having allowed pre-Directive periods of residence to count towards permanent residence, a logically subsequent question which the Court then had to address was how to treat absences from a Member State which were after the period on which the right of permanent residence was based, but also prior to 30 April 2006. In Lassal, that issue arose in relation to the applicant's physical absence from the Member State in question. The Court's solution was to apply the provisions of Article 16(4) by analogy, so that pre-Directive absences of less than two years would not count against the latent' right of permanent residence. In explaining this conclusion, the Court again relied upon the discourse of integration. In its view, the loss of the right of permanent residence after two years was justified, because 'after an absence of that duration the link with the host Member State is loosened'. ${ }^{49}$ In contrast, absences of less than two years were 'not such as to affect the link of integration of the citizen of the Union concerned'. 50

The Court's ruling in Dias then considered the implications of what may be termed 'legal' absences prior to 30 April 2006, i.e. periods during which a person was present on a Member State's territory, without having a right of

$\begin{array}{ll}48 & \text { Ibid., para } 37 . \\ 49 & \text { Ibid., para 55. } \\ 50 & \text { Ibid., para } 57 .\end{array}$


residence under EU free movement law. ${ }^{51}$ In its judgment in July 2011, the Court claimed to again apply Article 16(4) by analogy, and concluded that a person who was physically present on the territory without qualifying residence would retain the right of permanent residence only until they lacked qualifying residence for more than two years. That ensured protection for the person concerned, who was a Portuguese national who had been employed in the United Kingdom from 1998 to 2003 , but who had then been outside the labour market for a period of twelve months. But it denied protection to other persons who remained on a Member State's territory for longer periods without qualifying residence.

Here too, the text of the Directive made the Court's conclusion in Dias problematic. The relevant passage in Article 16(4) refers to 'absence from the host Member State', and therefore appears to cover physical absence from the territory alone. Had that interpretation been given in Dias, the latent right of permanent residence would have been retained for an indefinite period of non-qualifying residence, and there would have been a genuine analogy with post-Directive periods. In order to justify the restrictive conclusion that non-qualifying residence counted as an absence, the Court again relied upon ideas of social integration. It noted that, in Lassal, physical absences of more than two years had been thought to 'affect the link of integration of the Union citizen concerned'. It reasoned that 'the integration link between the person concerned and that Member State is also called into question in the case of a citizen who ... decides to remain in that Member State without having a right of residence'. In what would become a fundamental passage in the Court's jurisprudence on security of residence, it then declared that 'the integration objective which lies behind the acquisition of the right of permanent residence laid down in Article 16(1) ... is based not only on territorial and time factors but also on qualitative elements.' This new 'qualitative' interpretation of integration, linking it to qualifying residence, did not have any basis in the text of the Directive. It was moreover an example of an 'actively conditional' approach to integration, in that residence alone was treated as insufficient to prove integration. It would open the door to further restrictions on rights guaranteeing security of residence.

\subsection{Which Types of Residence?}

A second set of issues to come before the Court concerned the types of residence that count towards the right of permanent residence. The text of Article

51 Case C-325/og Secretary of State for Work and Pensions v. Dias, EU:C:2011:498 [2011] ECR I-6387. 
16 states that the right arises when an EU citizen or family member has 'resided legally' for five years in the Member State concerned. But what does that phrase cover? In particular, what of periods in which a person is lawfully resident, without qualifying residence under the Directive or its predecessors?

In Dias, the version of this question which arose was whether an EU citizen could count a period of non-qualifying residence during which they held a valid residence document issued in accordance with EU free movement law. In its judgment, the Court focused on the declaratory nature of such residence documents, in finding that they could not make residence lawful on their own. ${ }^{52}$ Given the potential for unfairness to individuals who had been relying upon such documents as confirmation of a right to reside, it is striking that, in this part of the ruling, it made no mention of social integration. The Court thereby avoided the argument that, in all periods when an EU citizen or family member is actually living in a Member State - and especially those in which they are ostensibly complying with immigration formalities - they are likely to be in the process of becoming socially integrated. The Court's rejection of reliance upon residence documents in Dias was though compatible with the 'qualitative' theory of integration set out elsewhere in the judgment. From that perspective, possession of residence documentation was irrelevant, as what mattered to 'integration' was the individual's compliance with the requirements for a right of residence under EU free movement law.

A similar analysis may be offered of the treatment of the meaning of 'resided legally' in Ziolkowski and Szeja. Could the individuals at issue there rely upon lawful residence in accordance with humanitarian permits issued under national law in order to establish a right of permanent residence? In its answer, the Court took an especially narrow view, holding that only qualifying residence under Article 7 of the Directive counted towards permanent residence. ${ }^{53}$ It offered three arguments for this conclusion. The first was that the Directive as a whole contains a 'gradual system as regards the right of residence': an unrestricted right of residence for up to three months, a right of ordinary residence for periods of longer than three months, and then a right of permanent residence after (usually) five years. ${ }^{54}$ The second concerned recital 17, which refers

$52 \quad$ Dias, para 54.

53 Because Ziolkowski concerned EU citizens, the Court stated that residence should comply with Article 7(1) of the Directive. The discussion here refers to Article 7 as a whole, as the Court's analysis is equally applicable to non-EU family members provided for in Article 7(2) of the Directive. That would be confirmed in Case C-529/11 Alarape and Tijani v. Secretary of State for the Home Department, ECLI:EU:C:2013:290, para 37.

54 Ziolkowski and Szeja, paras 38-41. A similar argument had been put forward by Advocate General Trstenjak in Dias: see paras 77-79 of her Opinion, EU:C:2011:86. 
to residence 'in compliance with the conditions laid down in this Directive'. ${ }^{55}$ The third was that, because qualification for permanent residence through Article 18 expressly requires compliance with residence under Articles 12(2) and $13(2)$ of the Directive, those seeking to rely upon Article 16 equally had to meet the conditions for ordinary residence set out in Article $7 \cdot{ }^{56}$ Each of these arguments is however open to the response that what the text of Article 16 requires is simply lawful residence. Where the meaning of a legislative provision is clear, and does not lead to an absurd result, one may question a different reading by reference to the legal-contextual arguments such as were deployed by the Court in Ziolkowski and Szeja.

The ruling on this point had the remarkable effect of precluding reliance not only upon lawful residence based upon national law, but also upon residence under rights in $E U$ free movement law other than Article 7 of the Directive. ${ }^{57}$ Three provisions of the Directive itself were thereby excluded. Its Article 6 confers what is expressly termed a 'right of residence' upon EU citizens and qualifying family members for up to three months in a Member State. without meeting substantive qualifying conditions. Its Article 12(3) permits the children of an EU citizen, and a parent who has actual custody of them, to remain after the EU citizen's death or departure, while the children complete their education. In addition, its Article 14(4)(b) creates an implicit right of residence: where an EU citizen entered a host Member State to seek employment, neither they nor their family members may be expelled, so long as the EU citizen is continuing to seek employment and has a genuine chance of being engaged. There are also three sources of EU free movement rights outside the Directive, which did not count towards permanent residence after Ziolkowski and Szeja either. Article 20 TFEU confers a right of residence upon family members, where that is necessary to give effect to the right of an EU citizen to reside in the EU. ${ }^{58}$ The right of EU citizens to move and reside freely within the territory of the Member States, set out in Article 21 TFEU, protects the family members of a Member State's national who has exercised those rights, even though that

\footnotetext{
55 Ziolkowski and Szeja, para 43. This argument had also been made by Advocate General Trstenjak in Dias: see para 76 of her Opinion.

56 Ziolkowski and Szeja, paras 44-45.

57 It should be noted that residence on the basis of Articles 12(2) and 13(2) of the Directive is expressly catered for by Article 18 of the Directive.

58 Case C-34/og Ruiz Zambrano v. Office National de l'Emploi, EU:C:2011:124 [2011] ECR I-1177 and Case C-256/11 Dereci and others v. Bundesministerium für Inneres, EU:C:2011:734 [2011] ECR I-11315.
} 
person falls outside the scope of the Citizens Directive. ${ }^{59}$ Finally, rights of residence for the children of EU migrant workers, and their primary carers, follow from secondary legislation on the free movement of workers. ${ }^{60}$ In Alarape, decided in May 2013, the Court confirmed that residence under the last of these does not count towards permanent residence. ${ }^{61}$ That may be taken as authority that residence under none of the sources listed in the paragraph counts towards permanent residence.

In reaching its interpretation of 'lawful residence' in Ziolkowski and Szeja, the Court again did not use the language of integration. Just as in Dias, that avoided the counter-argument that an EU citizen or non-EU family member who is lawfully resident on a basis other than Article 7 of the Directive is likely to be becoming socially integrated. ${ }^{62}$ The point had indeed been made by Advocate General Kokott in November 2010 in the case of McCarthy - where parallel issues were argued - that, from the perspective of social cohesion and integration, the source of a right of residence was 'of secondary importance.' ${ }^{63}$ That conclusion was endorsed by Advocate General Bot in his Opinion in Ziolkowski and Szeja. ${ }^{64}$ He illustrated the point by reference to the facts in those proceedings: one applicant had arrived in Germany at the age of 12, had completed their education there, and had had a child of German nationality, while the other had lived in Germany for 20 years, and her children had been born and had always lived there. In his view, it was likely that the applicants' integration was as 'complete' as that of other EU citizens who acquired a right of permanent residence through qualifying residence. ${ }^{65}$

The effect of this part of the ruling in Ziolkowski and Szeja was selection among lawful residents on economic and financial grounds, without clear textual support in the Directive. Periods of residence only counted towards

59 Case C-456/12 O. v. Minister voor Immigratie, Integratie en Asiel and Minister voor Immigratie, Integratie en Asiel v. B., EU:C:2014:135 and Case C-165/16 Lounes v. Secretary of State for the Home Department, EU:C:2017:862.

6o Echternach and Moritz and Baumbast (above, note 26).

61 Alarape (above, note 53).

62 For this observation, see the case note by M. Jesse (2012) 'Joined Cases C-424/10, Tomasz Ziolkowski v. Land Berlin, and C-425/10, Barbara Szeja, Maria-Magdalena Szeja, Marlon Szeja v. Land Berlin, Judgment of the Court of Justice (Grand Chamber) of 21 December 2011', 49 Common Market Law Review, Issue 6, p. 2003-2017, at p. 2016-2017.

63 Case C-434/og McCarthy v. Secretary of State for the Home Department, Opinion of Advocate General Kokott, ECLI:EU:C:2010:718, para 52. In McCarthy, the Court did not find it necessary to rule on the meaning of 'resided legally' in Article 16(1), as it held that dual nationals were excluded from the scope of the Directive.

64 Ziolkowski and Szeja, Opinion of Advocate General Bot, EU:C:2011:575, para 54.

65 Ibid., para 56. 
permanent residence for EU citizens who met the core requirements of economic activity or sufficient resources, and the family members of those persons. Other periods of lawful residence, even lengthy ones-whether under national law or other provisions of EU law - could not be relied upon. Despite the non-use of the language of integration in Ziolkowski and Szeja, its selective approach was therefore identical in substance to the 'qualitative' theory of integration that had previously been set out in Dias.

\subsection{Time Spent in Prison}

A third set of issues to come before the Court, relating to the implications of imprisonment for the right of permanent residence, were addressed by the Court in Onuekwere, decided in January 2014. ${ }^{66}$ Those proceedings concerned the refusal by the United Kingdom immigration authorities of a permanent residence card to the Nigerian spouse of an Irish national, even though they had lived together in the United Kingdom for more than ten years. The reason given by the for their refusal was that the applicant had spent two periods in prison, so that there was no five-year period of continuous residence he could rely upon. During those periods, however, he had arguably met the qualifying requirements under Article 7 of the Directive, as the spouse of an EU citizen, living in the same Member State as them. The question therefore was whether there was any specific rule against reliance upon periods of imprisonment.

The Court's treatment of such periods turned on the 'qualitative' theory of integration. It cited the reference to social cohesion in recital 17 to the Directive, and the reliance upon that in the Lassal judgment (above), in support of the proposition that 'the EU legislature ... made the acquisition of the right of permanent residence ... subject to the integration of the [person concerned] in the host Member State.' ${ }^{67}$ It then drew from its Dias ruling the conclusion that 'such integration ... is based not only on territorial and temporal factors but also on qualitative elements, relating to the level of integration in the host Member State. ${ }^{68}$ This 'qualitative' test could not be met where imprisonment had occurred, as 'the imposition of a prison sentence by the national court is such as to show the non-compliance by the person concerned with the values expressed by the society of the host Member State in its criminal law. ${ }^{29}$ Accordingly, the Court concluded that periods in prison did not count towards

66 Case C-378/12 Onuekwere v. Secretary of State for the Home Department, EU:C:2014:13.

67 Ibid., para 24. This passage refers to EU citizens in support of a conclusion about non-EU family members.

68 Ibid., para 25. This paragraph refers to Article 16(1), which concerns EU citizens, in support of a conclusion about Article 16(2), which concerns non-EU family members.

$69 \quad$ Ibid., para 26. 
the right of permanent residence, and that neither could periods of residence before and after imprisonment be added together in order to generate that right. ${ }^{70}$

These conclusions in Onuekwere applied to all prison sentences, irrespective of their duration. ${ }^{71}$ The Court ignored a suggestion during the proceedings to treat periods of imprisonment as analogous to absence from the territory, so that continuity of residence would have be maintained for a period of up to six months. ${ }^{72}$ It also disregarded a Commission proposal for a proportionality assessment as to whether time in prison could be relied upon, within which the duration of a sentence would have been a key factor. ${ }^{73}$ For those who had not acquired a right of permanent residence prior to imprisonment, the effect of the ruling was to prevent access to that right at a time-during and after a prison sentence-when it is likely to be especially significant in limiting the power of expulsion. The ruling also left open the further possibility - as yet untested before the Court - that persons who acquire the right of permanent residence before imprisonment might lose it on 'integration' grounds-for example, after two years, in line with Article 16(4) and the judgment in Dias.

The significance of Onuekwere lies in the Court's use of its integration discourse to narrow access to the right of permanent residence. The Court here treated permanent residence in an 'actively conditional' way, by making it 'subject to' integration in the Member State concerned. Indeed, the Onuekwere judgment went further than Dias in its use of the 'qualitative' dimension to integration: here, that required not only compliance with Article 7 conditions for residence, but also respect for the criminal law and the values of a host Member State. This conclusion lacked textual support within the Directive, and in particular, the Court's reliance upon recitals 17 and 18 at odds with their treatment of the right of permanent residence as a means to social cohesion and integration.

\section{$5 \quad$ Interpreting the Ten-year Rule}

Having been developed in cases concerned with the right of permanent residence, the Court's integration discourse would come to be deployed in

\footnotetext{
$70 \quad$ Ibid., paras 26 and 31 .

71 In particular, paras 26 and 31 of the judgment refer simply to the imposition of a prison sentence'.

72 The German Government had proposed that Article 16(3) be applied by analogy: see Opinion of Advocate General Bot in Onuekwere, EU:C:2013:640, para 60.

73 Ibid., para 61.
} 
interpreting the protection against expulsion conferred by Article 28(3) of the Directive upon EU citizens with ten years' continuous residence. ${ }^{74}$ We shall see that that has occurred in relation to both the substance of protection from expulsion, and the question of eligibility for protection under the ten-year rule. ${ }^{75}$

\subsection{The Substance of Protection}

The ten-year rule was first considered by the Court in Tsakouridis, decided in November 2010. ${ }^{76}$ That concerned a Greek national who had been born in Germany, and who had lived there until the age of 26 , before spending two periods totalling 24 months in Greece. After he had been convicted and imprisoned in Germany for involvement in drug trafficking, the German authorities ordered his expulsion. One of the legal questions which arose was whether expulsion after those offences was compatible with Article 28(3). In its judgment, the Court firstly gave a broad definition of the concept of 'imperative grounds of public security', stating that 'trafficking in narcotics as part of an organised group could reach a level of intensity that might directly threaten the calm and physical security of the population as a whole or a large part of it. ${ }^{77}$ In Tsakouridis, the language of integration was then used to protect the rights of individuals with (or assumed to have) ten years' continuous residence, by preventing expulsion from being the automatic consequence of a finding of imperative grounds of public security. In the Court's view, a balancing exercise was required, within which the state authorities were to consider the possible negative implications for the social rehabilitation of a person of expulsion from the country in which they were 'genuinely integrated. ${ }^{78}$ Furthermore, fundamental rights to family and private life had to be respected, which meant taking account both of the person's duration of residence in the given state and of 'the solidity of the social, cultural and family ties with the host Member State'. ${ }^{79}$

The integration discourse would though have a different role in $P I$, decided in May 2012. ${ }^{80}$ That concerned an Italian national citizen who had committed

74 To date, no cases have addressed the application of Article 28(3) to minors.

75 This sequence is adopted because a discourse of integration was initially deployed to give a broad construction of 'imperative grounds' (in the PI case), and only later to limit eligibility (in the $M G$ case). Had the second happened first, it is possible that 'imperative grounds' would not have been given such a broad construction.

76 Case C-145/og Land Baden-Württemberg v. Tsakouridis, EU:C:2010:708 [2011] ECR I-11979.

77 Ibid., para 47.

78 Ibid., para 49.

79 Ibid., paras 52 and 53, citing Maslovv. Austria, ECtHR application no. 1638/o3, judgment of 23 June 2008 (Grand Chamber), paras 71-75.

80 Case C-348/og PI v. Oberbürgermeisterin der Stadt Remscheid, EU:C:2012:300. 
a series of sexual offences against a child during the ten years' residence in Germany that he sought to rely upon. Faced with this case, Advocate General Bot advised the Court to introduce an integration pre-condition to eligibility for protection under Article $28(3) .{ }^{81}$ As he put it: 'It seems clear to me that Mr I.'s conduct, which constitutes a serious disturbance of public policy, shows a total lack of desire to integrate into the society in which he finds himself and some of whose fundamental values he so conscientiously disregarded for years. ${ }^{82}$

The Court instead took a different route to limiting protection, by broadening the concept of 'public security'. Borrowing the language of Tsakouridis, it concluded that it was open to Member States to treat sexual offences against children as 'constituting a particularly serious threat to one of the fundamental interests of society, which might pose a direct threat to the calm and physical security of the population', so as to be covered by the concept of 'imperative grounds of public security'. ${ }^{83}$ That was a questionable interpretation of the Directive, as it went further than the decision in Tsakouridis, by permitting the category of 'public security' to extend to behaviour in the private sphere which was repugnant to the general public. ${ }^{84}$ Although the Court did not use the language of integration in its judgment, nevertheless its conclusion that (in effect) any behaviour which conflicted with fundamental social values was a threat to 'security' was consistent with the 'actively conditional' approach whereby protection depends upon actual social integration.

\subsection{Eligibility}

The conceptual difficulties with a broad interpretation of 'imperative grounds of public security' in the context of criminal offences may explain why, in judgments subsequent to $P I$, the Court limited eligibility for protection under Article 28(3). In Tsakouridis, a further question which had come before the Court was how-without an equivalent in Article 28 to Articles 16(3) and 16(4) - absences from a Member State should be treated in calculating ten years' continuous residence. The Court's answer was that the 'decisive criterion' was whether the person had lived in the Member State throughout the ten years preceding the decision to expel. ${ }^{85}$ Where a person had been absent

\footnotetext{
81 Opinion of Advocate General Bot in PI, EU:C:2012:123, paras 49-66.

82 Ibid., para 60.

83 Judgment in PI, para 28.

84 L. Azoulai \& S. Coutts (2013) 'Restricting Union Citizens' Residence Rights on Grounds of Public Security. Where Union Citizenship and the AFSJ Meet', 50 Common Market Law Review, p. 553-570, at p. 559-563.

85 Judgment in Tsakouridis, para 31.
} 
from the territory, the question for the national authorities was whether there had been a transfer to another state of 'the centre of the personal, family or occupational interests of the person concerned. ${ }^{\prime 86}$ A broad range of factors were to be considered as part of this 'overall assessment', the purpose of which was 'determining whether the integrating links previously forged with the host Member State [had] been broken' ${ }^{87}$

In Tsakouridis, 'integration' was used to protect an individual, by making it less likely that an EU citizen's 'centre of interests' would be found to have moved from the Member State in question. That approach tended however to elevate 'integration' to something approaching a substantive condition for protection, which would not necessarily protect EU citizens in all cases. The language of 'integration' would then be used to quite different effect in the Court's ruling in $M G$, decided in parallel with Onuekwere in January $2014 .^{88}$ That concerned a Portuguese national who had resided for more than 11 years in the United Kingdom, before being convicted of harming a child, as a result of which she spent 11 months in prison. If she was eligible for protection under Article 28(3)(a), deportation was precluded, as there were no apparent 'imperative grounds of public security' in the case. ${ }^{89}$

In its answer, the Court followed the reasoning in Onuekwere. The central question was whether the ten-year rule applied to a person who had spent time in prison within the previous decade. Firstly, 'the fact that a national court has imposed a custodial sentence is an indication that the person concerned has not respected the values of the society of the host Member State, as reflected in its criminal law'. ${ }^{90}$ Secondly, 'the degree of integration of the persons concerned [was] a vital consideration underpinning ... the system of protection against expulsion measures established by Directive 2004/38'. ${ }^{\prime}$ It followed that periods in prison could not be taken into account for the purpose of the ten-year rule, and that 'in principle' such periods interrupted continuity of residence for that purpose. ${ }^{92}$

Had this conclusion been applied in full, it would have neutralised the ten-year rule in most cases, as EU citizens would have been unable to rely upon its protection while they were in prison, or in the ten years after their release. Citing Tsakouridis, the Court therefore sought to soften the force

$86 \quad$ Ibid., para 33 .

$87 \quad$ Ibid., para 34.

88 Case C-40o/12 MG v. Secretary of State for the Home Department, EU:C:2014:9.

89 Judgment of the referring court, MG Portugal, [2012] UKUT 00268 (IAC), para 13.

9o $\quad M G$, para 31 .

91 Ibid., para 32.

92 Ibid., para 33. 
of its approach, by allowing that a person might nevertheless benefit from Article 28(3) on the basis of 'an overall assessment ... of that person's situation', in order to 'determin[e] whether the integrating links previously forged with the host Member State have been broken. ${ }^{93}$ Within that assessment, account was to be taken both of periods in prison, and of periods of residence in the Member State prior to imprisonment. ${ }^{94}$ An EU citizen who had spent time in prison in the ten years prior to an expulsion benefitted from Article 28(3) only if they were (still) considered to be 'integrated' in that Member State. Unlike in Tsakouridis, however, the overall question was no longer where a person's centre of interests lay, but rather whether 'integrating links' had been maintained, something which was far less likely to lead to positive outcome for the individual.

The use of concepts of integration to determine eligibility for Article 28(3) protection would continue in the joined cases of $B$ and Vomero, in which the Court gave judgment in April 2018. ${ }^{95}$ The 'B' part of the proceedings concerned a Greek national who had lived in Germany from the age of three or four, and who, at the age of 24 , had been convicted of armed robbery and sentenced to imprisonment for five years and eight months. When he challenged a subsequent expulsion decision, made after 19 months in prison, the national court sought clarification of the meaning and assessment of 'integrative links', as it doubted whether those could have been broken by imprisonment in these factual circumstances. In its judgment, the Court elaborated on ways in which an 'overall assessment' could lead to the conclusion that a person who had spent time in prison remained integrated in a state. Firstly, persons with very long periods of residence were likely to remain eligible for protection: 'the more those integrative links with that State are solid-including from a social, cultural and family perspective ...- the lower the probability that a period of detention could have resulted in those links being broken. ${ }^{96}$ Secondly, a person's attitude while in prison could be critical, as it might either 'reinforce' their disconnection from that society, or else 'help to maintain or restore links previously forged with the host Member State with a view to [their] future social reintegration in that State. ${ }^{97}$ These two statements served to relax the implications of the presumption that imprisonment negatived protection under

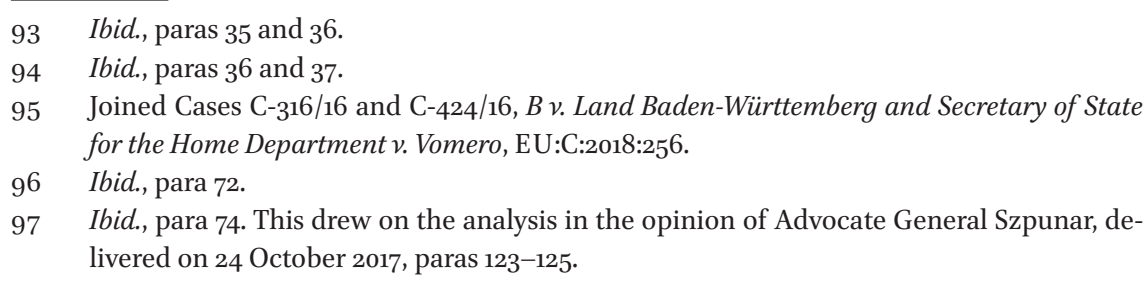


Article 28(3). At the same time, they confirmed the underlying 'actively conditional' approach that protection against expulsion for those who have lived for more than ten years in a state depended upon their being integrated there, with imprisonment a strong indicator that they were not.

The 'Vomero' part of the judgment concerned an Italian national who had moved to the United Kingdom as an adult in 1985, and who was convicted of manslaughter in 2002. He had been in prison from 2001 until July 2006, and a decision to deport him was taken in March 2007. In the light of the ruling in Onuekwere, the United Kingdom Supreme Court took the view that he could not have acquired a right of permanent residence when the Directive came into force on 30 April 2006. ${ }^{98}$ As he had not acquired a right of permanent residence subsequently either, the possibility for him to resist deportation using EU law therefore depended on his being protected by Article 28(3). Accordingly, the Supreme Court asked whether possession of the right of permanent residence was a precondition to Article 28(3) protection. ${ }^{99}$ The Court's answer treated 'integration' as the organising principle. The Directive's system of protection against expulsion was 'based on the degree of integration of those persons in the host Member State,' and 'gradually increase[d] in proportion to the degree of integration of the Union citizen concerned in the host Member State.' ${ }^{100}$ Moreover, the right of permanent residence was 'subject to the integration of the citizen of the Union in the host Member State', while 'integration ... [was] based not only on territorial and temporal factors but also on qualitative elements.' ${ }^{101}$ For both reasons, the Court considered that it would be at odds with the scheme of the Directive for a person who lacked a right of permanent residence to benefit from the ten-year rule.

The net result of the Court's rulings in Tsakouridis, $M G$ and $B$ and Vomero is that, in the typical case where a person being expelled is in prison, or has been so in the recent past, protection under the ten-year rule is dependent upon their being considered integrated in the Member State in question. In the context of a criminal conviction and imprisonment, that test will often be difficult to meet, especially by those who moved to the Member State after their early years. Once again, it may be observed that this test has no clear basis in the text of the Directive.

98 Secretary of State for the Home Department $v$. Vomero, [2016] U KSC 49.

99 For examples of cases where there may be ten years' continuous residence without a right of permanent residence, see the Opinion of Advocate General Szpunar, EU:C:2017:797, para 48.

$100 \quad$ Judgment in $B$ and Vomero, paras 44 and 48.

$101 \quad$ Ibid., paras 57 and 58. 
This article has shown how the Court of Justice has elaborated a discourse of migrant integration in order to justify restrictive interpretations of the rights of security of residence added by the Citizens Directive. After an early ruling (Lassal) in which the language of integration improved the individual's position, and another (Tsakouridis) in which it softened a narrow reading of the Directive, the integration frame of reference generally worked to individuals' detriment. The Court's approach has been based upon two legally questionable propositions: that the Directive makes rights of security of residence 'subject to' integration (first stated in Lassal) and that, under the Directive, integration has a 'qualitative' dimension (first stated in Dias). Social integration has been expressly used to justify the following propositions: that 'legal' absences count against a person's retention of a latent pre-Directive right to permanent residence (Dias), that periods of imprisonment break continuity of residence (Onuekwere, $M G$ ), that protection under the ten-year rule is conditional upon social integration in the Member State in question $(M G$ and $B$ and Vomero), and that protection under the same rule requires possession of the right of permanent residence ( $B$ and Vomero). Even those elements within these rulings in which integration was not mentioned-concerning residence documents in Dias, residence under national law in Ziolkowski and the meaning of 'imperative grounds of public security' in $\mathrm{PI}$ - fitted squarely within the Court's 'qualitative' and 'actively conditional' approach to integration.

Previous literature on the case law concerning security of residence under the Citizens Directive has focused on the critique of individual rulings. ${ }^{102}$ The analysis in this article added to that literature by showing that the Court's integration discourse is the unifying idea which links this jurisprudence together. It has to be presumed that the Court's development of an interpretative approach based on the social integration of migrants reflected the wider policy context from around 2000, within which exactly this question was posed in Member States with established populations of foreign origin. As we have seen, there had moreover been specific prompts to act at the EU level, including the provision for integration requirements in the two directives concerning third-country nationals adopted in 2003 and the development of an EU-level

102 In relation to Ziolkowski and Szeja, see Jesse 2012 and A. Łazowski (2013) 'Children of the lesser law', 38 European Law Review, p. 404-418. In relation to PI, see Azoulai \& Coutts 2013. In relation to Onuekwere and $M G$, see U. Belavusau \& D. Kochenov (2016) 'Kirchberg dispensing the punishment: Inflicting "civil death" on prisoners', 41 European Law Review, p. 557-577 and S. Coutts (2015), 'Union citizenship as probationary citizenship' 52 Common Market Law Review, p. 531-545. 
integration policy. The references to 'integration' within the Citizens Directive may also have encouraged the Court's approach, even though they confirmed the older egalitarian view that security of status promotes integration, or reflected the moderate position that integration flows from residence. ${ }^{103}$

The Court's recourse to creative interpretation in order to limit security of residence rights under the Directive is at odds with its history of judicial activism to promote free movement. ${ }^{104}$ The result is an approach which has been selective as to the foreign nationals who are to be protected, with the Court favouring EU citizens who are economically active or self-sufficient, together with their family members, provided they do not commit criminal offences. There is a clear affinity between this case-law and the Court's decisions in recent years which have denied the protection of EU free movement law to EU citizens who are unemployed. ${ }^{105}$ What this article has shown is that the Court has emerged as a surprise contributor to the 'turn' in public policy which has made foreign nationals' residence rights contingent upon meeting ideals of social integration.

103 This conclusion is not affected by the fact that one member of the Court-Judge Silva de Lapuerta - acted as rapporteur in seven of the cases considered here: Lassal, Dias, Ziolkowski and Szeja, Alarape, Onuekwere, MG and Ogieriakhi. Judge Silva de Lapuerta was also a member of the Court in B and Vomero, though not in Tsakouridis or PI. The possibility that one or more individual judges may have had a particular role in the formation of the Court's position in a given area tends to reinforce the view that the Court has responded to the external policy environment. In any event, as the Court's rulings are endorsed by all the judges involved, it is defensible to treat them as expressing a corporate view.

104 On the Court's historic activism, see D. Thym (2013) 'Towards "Real" Citizenship? The Judicial Construction of Union Citizenship and its Limits', in: M. Adams, J. Meeusen, G. Straetmans \& H. de Waele (eds), Judging Europe's Judges. The Legitimacy of the Case Law of the European Court of Justice Examined (Oxford, Hart).

105 Case C-333/13 Dano v. Jobcenter Leipzig, EU:C:2014:2358 and Case C-67/14Jobcenter Berlin Neukölln v. Alimanovic and others, EU:C:2015:597. 
